\title{
Electrohemical Behavior of Molten Imidazole with Strong Acids
}

\section{Bandur, Viktor; Li, Qingfeng; Bjerrum, Niels}

Published in:

Meeting Abstracts - Electrochemical Society

Publication date:

2009

Document Version

Publisher's PDF, also known as Version of record

Link back to DTU Orbit

Citation (APA):

Bandur, V., Li, Q., \& Bjerrum, N. (2009). Electrohemical Behavior of Molten Imidazole with Strong Acids. In Meeting Abstracts - Electrochemical Society (pp. Abstract 3071). The Electrochemical Society.

\section{General rights}

Copyright and moral rights for the publications made accessible in the public portal are retained by the authors and/or other copyright owners and it is a condition of accessing publications that users recognise and abide by the legal requirements associated with these rights.

- Users may download and print one copy of any publication from the public portal for the purpose of private study or research.

- You may not further distribute the material or use it for any profit-making activity or commercial gain

- You may freely distribute the URL identifying the publication in the public portal

If you believe that this document breaches copyright please contact us providing details, and we will remove access to the work immediately and investigate your claim. 


\section{Electrochemical behaviour of molten Imidazole with the strong acids Viktor Bandur, Qingfeng Li, and Niels Bjerrum \\ ${ }^{1}$ Department of Chemistry, Kemitorvet, Building 207, Technical University of Denmark, 2800 Kgs. Lyngby DENMARK}

Ionic liquids (ILs) consist entirely of ions and have attracted considerable attention because of their unique properties such as nonflammability, negligible volatility, high ion conductivity, thermal and chemical stability, and so on. ${ }^{1-5}$ With the aim towards innovating proton conducting ionic liquids for anhydrous proton conductors at elevated temperatures imidazole was selected to provide electrochemically insight into this kind of proton conduction.

The new superstrong acids, when mixed with imidazole as a Brønsted base, form an ionic liquid. Protonation of the base with the acids was found to promote the proton conductivity significantly:

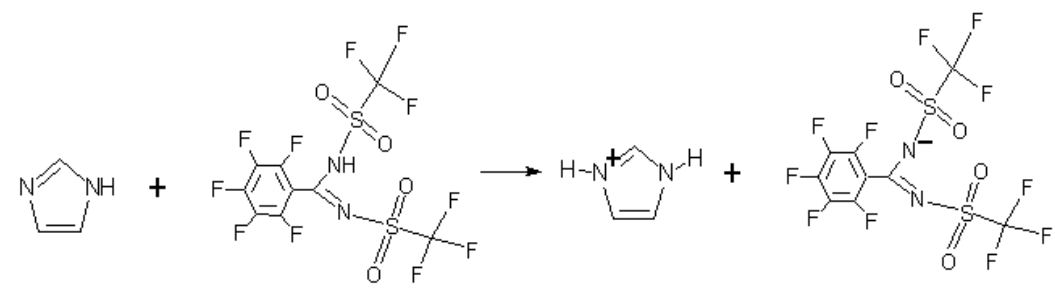

Conductivity of imidazole ( $\mathrm{Im}$ ) - with addition of a strong acid (SA) has been measured at $120{ }^{\circ} \mathrm{C}$ as a function of the binary composition. Four new aryl super acids have been investigated, one shown in Figure 1. All the acids showed similar effects. By adding a few mol percent of these acids, conductivity of the melt is dramatically increased

On a smooth platinum electrode, the voltammetric current for the cathodic oxidation is also found to significantly increase as the concentration of the acids is increased from zero to about $5 \mathrm{~mol} \%$, indicating enhancement of the electrode kinetics. Further addition of the acid leads, however, to a decrease in the hight of the peaks. An explanation of these results are still under discussion.
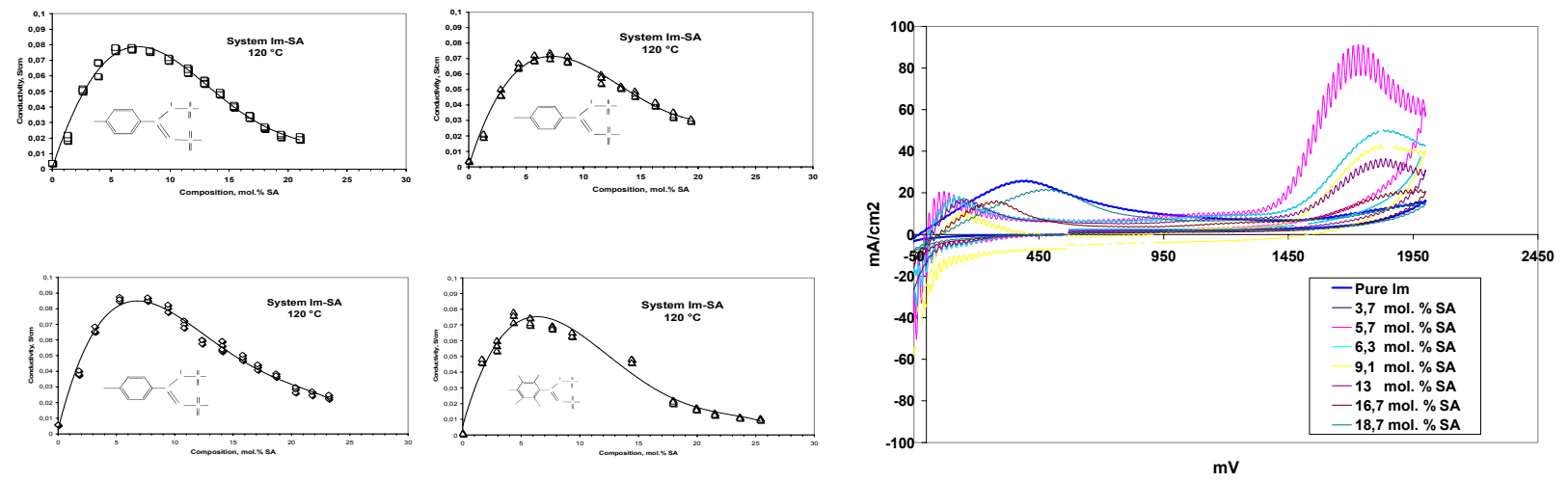

Figure 1. Dependence of the conductivity from composition for the molten system.

Fig.2. Cyclic voltammograms in the imidazole-fluorophenyl acid system at $120^{\circ} \mathrm{C}$. Scan rate was $1000 \mathrm{mV} / \mathrm{s}$. Concentration of the acid was indicated in the figure.

1 Welton, T. Chem. ReV. 1999, 99, 2071.

2 Holbrey, J. D.; Seddon, K. R. Clean Prod. Process 1999, 1, 223.

3 Wasserscheid, P.; Keim, W. Angew. Chem., Int. Ed. 2000, 39, 3772.

4 Ionic liquids IIIB: Fundamentals, Progress, Challenges, and Opportunities Transformations and Processes; Rogers, R. D.,

Seddon, K. R., Eds.; ACS Symposium Series 902; American Chemical Society: Washington, DC, 2005.

5 Wilkes, J. S. Green Chem. 2002, 4, 73. 